\title{
FOREST LITTER DECOMPOSITION AS AFFECTED BY EUCALYPTUS STAND AGE AND TOPOGRAPHY IN SOUTH-EASTERN BRAZIL ${ }^{1}$
}

\author{
Alba Lucia Araujo Skorupa ${ }^{2}$, Nairam Félix de Barros $^{3}$ e Júlio César Lima Neves ${ }^{3}$
}

\begin{abstract}
Forest litter decomposition is a major process in returning nutrients to soils and thus promoting wood productivity in the humid tropic. This study aimed to assess decomposition of eucalypt litter in the Rio Doce region, Brazil. Leaf litter was sampled under clonal eucalypt stands aged 2, 4 and 6 years on hillslopes and footslopes. Soil and soil+litter samples were incubated at two levels of soil moisture, temperature and fertilization. $\mathrm{C}-\mathrm{CO}_{2}$ emissions from soil measured during 106 days were higher at $32{ }^{\circ} \mathrm{C}$ than at $23^{\circ} \mathrm{C}$, mainly for the 2-yr-old stand on footslope. When leaf litter was added on soils, $\mathrm{C}-\mathrm{CO}_{2}$ emissions were eight times higher, mainly on footslopes, with no effect of stand age. Leaf decomposition in situ, assessed with a litterbag experiment showed a mean weight loss of at least $50 \%$ during 365 days, reaching $74 \%$ for 2 yr-old stands on footslopes. In comparison with data from the native forest and the literature, no apparent restrictions were found in eucalypt litter decomposition. Differences between in vitro and in situ results, and between eucalypt and native forest, were most likely related to the response of diverse decomposer communities and to substrate quality.
\end{abstract}

Keywords: Soil respiration; Litterbag; $\mathrm{CO}_{2}$ evolution.

\section{DECOMPOSIÇÃO DE SERAPILHEIRA FLORESTAL: EFEITO DA IDADE DO EUCALIPTO E TOPOGRAFIA NO SUDESTE DO BRASIL}

\begin{abstract}
RESUMO - A decomposição de serapilheira florestal é um processo importante ao retornar nutrientes ao solo e, assim, estimular a produtividade da madeira no trópico úmido. Este trabalho objetivou avaliar a decomposição de serapilheira de eucalipto na região do rio Doce, MG. Frações foliares foram amostradas em plantações de eucalipto nas idades de 2, 4 e 6 anos e posições de encosta e baixada. Amostras de solo e solo + fragmentos de folhas foram incubadas em dois niveis de umidade, temperatura e fertilização. A quantidade de $\mathrm{C}-\mathrm{CO}_{2}$ emitida pelo solo no período de 106 dias foi maior na temperatura de incubação de $32{ }^{\circ} \mathrm{C}$ do que a $23{ }^{\circ} \mathrm{C}$, especialmente em solos de baixada, na idade de 2 anos. A respiração do solo foi intensificada oito vezes pela presença de fragmentos de folhas sobre o solo, principalmente em solos da baixada, e não houve efeito significativo para a idade. A decomposição foliar in situ, avaliada em um experimento de sacos de decomposição, apresentou perda média de no mínimo 50\% durante 365 dias, alcançando 74\% para o eucalipto em dois anos, na baixada. Após a comparação com uma mata nativa e dados da literatura nacional, não foi encontrada nenhuma restrição aparente na decomposição da fração foliar do eucalipto. Diferenças entre os resultados in vitro e in situ e entre a mata nativa e o eucalipto podem estar relacionadas a uma diferente comunidade de decompositores e à qualidade do substrato foliar.
\end{abstract}

Palavras-chave: Respiração do solo; Sacos de decomposição; Emissão de $\mathrm{CO}_{2}$.

\footnotetext{
${ }^{1}$ Recebido em 24.07.2012 aceito para publicação em 21.10.2015.

${ }^{2}$ Universidade Federal de Viçosa, Centro de Ciências Agrárias, Departamento de Engenharia Florestal, Viçosa, MG - Brasil. E-mail: <albaskorupa@hotmail.com>.

${ }^{3}$ Universidade Federal de Viçosa, Centro de Ciências Agrárias, Departamento de Solos, Viçosa, MG - Brasil. E-mail: <julio_n2003@yahoo.com.br>e<nfbarros@ufv.br>.
} 


\section{INTRODUCTION}

Forest litter decomposition plays an important role in returning nutrients to soil, and is critical to the productivity of fast-growing tree plantations in the humid tropics. However, there have been reports of intense litter accumulations ( $\left.>25 \mathrm{Mg} \mathrm{ha}^{-1}\right)$ under eucalypt stands in Southeastern Brazil (Gama-Rodrigues et al., 2008; Palha Leite, F., unpublished data), raising concern about proper nutrient cycling. Identifying the causes of such unbalances can be difficult since factors such as phenology and litter quality interact with the biotic and abiotic environment, and also because of seasonal and yearly climate variation. Measuring litter decomposition processes is important in assessing litter dynamics, but difficult because decay rates and decomposer organisms vary over time and space (PRESCOTT, 2005). Additionally, stand age and position in the landscape can affect the decomposition process because of their effect on litter production and site properties, but this has seldom been studied (BARGALI, 1996; ALVAREZ-SÁNCHES; ENRÍQUEZ, 1996).

This study aimed to investigate potential restrictions to eucalypt litter decomposition and nutrient cycling in the Doce River region, which may be related to stand age, topographic position, temperature, soil moisture and fertility. To test this hypothesis, leaf litter from different combinations of ages and topographic positions were incubated at different temperatures, soil moistures and fertilizations. In addition, a litterbag experiment was established to assess decomposition and nutrient release in situ.

\section{MATERIALAND METHODS}

The study area is located in the Doce River near Belo Oriente, Minas Gerais, Brazil (19 $18^{\circ}$ 'S and $\left.42^{\circ} 22^{\prime} \mathrm{W}\right)$, with a mean altitude of $336 \mathrm{~m}$ above sea level. The natural vegetation is semi-deciduous tropical forest. According to the Koeppen classification, the climate is a tropical humid, with mean annual temperature and precipitation of $25.2^{\circ} \mathrm{C}$ and $1,000-1,280 \mathrm{~mm}$, respectively. In general, the rainy season is from October to March, comprising about $80 \%$ of mean annual precipitation. Potential annual evapotranspiration varies from 950 to $1,200 \mathrm{~mm}$, with an annual water deficit between 30 and $90 \mathrm{~mm}$. The dominant soils in the area are Oxisols and Ultisols of clayey texture developed from Proterozoic granite and gneiss. Soil used in this incubation has $\mathrm{pH}$ values from 4.4 to 5.9, and soil organic matter between 13 and $18 \mathrm{~g} \mathrm{~kg}^{-1}$ under eucalypt stands. Under native forest, soil organic matter is higher $\left(28 \mathrm{~g} \mathrm{~kg}^{-1}\right)$, and soil pH is 5.9 .

Soil and leaf litter were sampled in December $7^{\text {th }}$ 2000, under Eucalyptus grandis x E. urophylla hybrid clonal stands ( $3 \times 2.5 \mathrm{~m}$ spacing) aged 2,4 and 6 yrs on footslope and hillslope positions, and under a native forest on the footslope. For each combination of stand age and topographic position, recently abscised leaves, varying from green to yellow-green colors, were collected in triplicate on the forest floor and stored at $4-7^{\circ} \mathrm{C}$ for the $\mathrm{CO}_{2}-\mathrm{C}$ evolution assessment. Leaf lignin was determined by the acid detergent fiber method of Van Soest and Wine (1968). In each sampling plot described above, soil from the $0-20 \mathrm{~cm}$ depth was sampled and stored at $4-7^{\circ} \mathrm{C}$ for two weeks before incubation.

Soils were incubated with and without leaf litter fragments. The sampled leaf material was air-dried and cut to approximately $0.5 \times 0.5 \mathrm{~cm}$ fragments. Subsequently, $15 \mathrm{~g}$ of leaf fragments were brought to $80 \%$ water retention capacity and placed onto $50 \mathrm{~g}$ of air-dried soil sieved $<2 \mathrm{~mm}$ contained in $0.6 \mathrm{dm}^{3}$ glass jars. Incubations were conducted at two levels of temperature, moisture and fertilization. The average minimum and maximum monthly temperatures of the region, respectively 23 and $32^{\circ} \mathrm{C}$, were used. Soil moistures were 40 and $80 \%$ of the water holding capacity. Fertilization levels were 0 and $5 \mathrm{~mL}$ of a solution with $50 \mathrm{mg} \mathrm{L}^{-1} \mathrm{P}\left(\mathrm{KH}_{2} \mathrm{PO}_{4}\right)$, $80 \mathrm{mg} \mathrm{L}^{-1} \mathrm{~N}\left(\mathrm{NH}_{4} \mathrm{Cl}\right)$, and $80 \mathrm{mg} \mathrm{L}^{-1} \mathrm{~K}(\mathrm{KCl})$.

The $\mathrm{CO}_{2}$ evolved was trapped with $\mathrm{NaOH}$ and titrated with $\mathrm{HCl}$ using phenolphthalein as indicator, after addition of $\mathrm{BaCl}_{2}$ to precipitate sodium carbonate (ANDERSON, 1982). The first titration was done after 2 days of incubation, followed by a new incubation for 3 days and titration, and so on, for $4,6,8,10,12$, 14, 20, and 27 days, in a total of 106 days. Results were expressed in $\mathrm{CO}_{2}-\mathrm{C} \mathrm{mg} \mathrm{g}^{-1}$ soil evolved, according to the formula:

$$
\mathrm{C}-\mathrm{CO}_{2}=\frac{[\mathrm{HCl}] \times f \times 6 \times(\mathrm{Vb}-\mathrm{Va})}{50 \mathrm{~g} \text { of soil }}
$$

where $[\mathrm{HCl}]=\mathrm{HCl}$ concentration; $\mathrm{f}=$ correction factor for $\mathrm{HCl}$ concentration; 6 = equivalent $\mathrm{mg}$ of $\mathrm{C}$ $\mathrm{CO}_{2} \mathrm{Vb}=$ volume $(\mathrm{mL})$ of $\mathrm{HCl}$ spent with blank; $\mathrm{Va}=$ volume $(\mathrm{mL})$ of $\mathrm{HCl}$ spent to titrate $\mathrm{NaOH}$ from samples. 
The experimental design was a completely randomized factorial design, in which the main factors were stand ages in three levels (2, 4 and 6 yrs) and topographic positions in two levels (footslope and hillslope), summing up to six main plots. Additionally, a split-plot was used, as each main plot was subdivided into a combination of three incubation factors in two levels: soil moisture, temperature and fertilization, resulting in eight subplots. As a reference, a nearby native forest on the footslope was sampled and compared with the eucalypt stands on the footslope. Data on accumulated C- $\mathrm{CO}_{2}$ after 106 days were submitted to analysis of variance followed by the least significant difference (LS Means STDERR PDIFF) or the Ryan-Einot-Gabriel-Welch Q (REGWQ) test of means (SAS, 1990).

A litterbag experiment was set to determine in situ decomposition rates of leaf litter. In each of the eucalypt plots mentioned above, 24 nylon bags of $23 \times 23 \mathrm{~cm}$ (3-mm mesh) filled with $40 \mathrm{~g}$ of recently fallen leaves were placed on the soil between tree rows. Four litterbags were retrieved at intervals of 52 (December. $\left.12^{\text {th }}\right), 64$ (February. 20 ${ }^{\text {th }}$ ) days, 46 (April $7^{\text {th }}$ ) and 203 days (October. $\left.24^{\text {th }} 2001\right)$. The total number of litterbags was 432 ( 3 ages $\mathrm{x} 2$ slopes $\mathrm{x} 3$ replicates $\mathrm{x} 6$ samplings $\mathrm{x} 4$ subsamples). Due to technical difficulties, the $5^{\text {th }}$ and $6^{\text {th }}$ samplings were done together in Oct. $24^{\text {th }}, 2001$. In addition, 54 litterbags ( 3 replicates x 6 samplings x 3 subsamples) containing a mixture of recently fallen leaves were distributed randomly in the native forest, and retrieved as above. The leaf material in litterbags was oven-dried at $75^{\circ} \mathrm{C}$, weighted and analysed chemically. About 0.5 $\mathrm{g}$ of fresh ground litter material was digested with concentrated $\mathrm{HNO}_{3}$ and $\mathrm{HClO}_{4}$ (JONES; CASE, 1990). From the digest, P (Olsen; Sommers, 1982) and B were determined by spectrometry; $\mathrm{K}$ and $\mathrm{Na}$ by flame photometry, $\mathrm{Ca}, \mathrm{Mg}, \mathrm{Cu}, \mathrm{Mn}$ and $\mathrm{Zn}$ by atomic absorption. Total nitrogen was determined by the Kjeldahl method (BREMNER; MULVANEY, 1982). Total carbon was estimated by weight loss on ignition at $550^{\circ} \mathrm{C}$ (JONES; CASE, 1990).

\section{RESULTS}

\subsection{Leaf litter quality}

Table 1 shows the initial nutrient, carbon and lignin concentrations in the leaf litter according to stand age and topographic position. Total $\mathrm{N}$ was higher in leaf litter of 2-yr-old stands compared to 4- and 6-yr-old stands. There was no effect of topographic position on nutrient concentrations. No significant differences were found for carbon, lignin concentration and $\mathrm{C}: \mathrm{N}$, $\mathrm{C}: \mathrm{P}$ and lignin: $\mathrm{N}$ ratios in eucalypt leaf litter due to stand age and topographic position. The mean $\mathrm{C}: \mathrm{N}$ ratio of eucalypt leaf litter was 40:1, similar to values reported by Sodré (1999) in Southeast Bahia, Brazil. Leaf litter from the native forest showed high concentrations of $\mathrm{Ca}, \mathrm{Mg}, \mathrm{N}, \mathrm{K}, \mathrm{Cu}$ and $\mathrm{B}$ compared to eucalypt litter.

\subsection{C-CO evolved}

The accumulated soil respiration after 106 days was affected mainly by temperature and stand age $(\mathrm{P}<0.01)$, and secondarily by slope $(\mathrm{P}=0.052)$. In general, soil respiration was significantly higher at age 2 yrs on the footslope (Table 2), and was not affected by moisture and fertilization. When leaf fragments were added on soils, the total $\mathrm{C}-\mathrm{CO}_{2}$ released was affected significantly by temperature and slope $(\mathrm{P}<0.01)$, but not stand age and moisture (Table 2). Presence of leaf litter fragments on soils increased the $\mathrm{C}-\mathrm{CO}_{2}$ evolved up to 8-fold, when compared to soil respiration (Table 2).

The $\mathrm{C}-\mathrm{CO}_{2}$ evolved was compared among the three eucalypt stand ages and the native forest on footslope position. Despite the lower soil respiration for stand age 4 yrs, there were no major differences under the two vegetation types (not shown). The total C-CO evolved during the experiment was better described by linear functions (Figure 1), in which intercepts and slopes were higher at $32^{\circ} \mathrm{C}$ compared to $23^{\circ} \mathrm{C}$, in both topographic positions and vegetation types.

\subsection{Litterbag experiment}

Litterbag weight loss was fast during the first 60 days, and then slowed down, with little change after 154 days. Weight loss after 120 days was generally lower for stands aged 4 and 6 yrs, compared to the 2 -yr stands, reaching ca. $48 \%$ by 365 days. The weight loss was higher under 2-yr-old stands, reaching 74\% on footslopes, and 58\% on hillslopes, in the 116-365 days period. As a comparison, litterbags in the native forest on footslope showed a weight loss of $68 \%$. However, decomposition rates in the native forest followed a contrasting pattern, being initially lower, increasing in the 52-116 day period, then becoming comparable to eucalypt decomposition rates in the 116365 day period (Figure 2). 
Table 1 - Mean concentrations of nutrients, carbon, lignin and C:N, C:P and lignin:N ratios in leaf litter from eucalypt stands aged 2, 4 and 6 yrs, and native forest.

Tabela 1 - Média de concentrações de nutrientes, carbono, lignina e taxas de C:N, C:P and lignin: $N$ em frações foliares de povoamentos de eucalipto nas idades de 2, 4 e 6 anos e em uma floresta nativa.

\begin{tabular}{|c|c|c|c|c|c|c|c|c|c|c|c|c|c|c|c|}
\hline Age & Slope & $\mathrm{N}$ & $P$ & $\mathrm{~K}$ & $\mathrm{Ca}$ & $\mathrm{Mg}$ & $\mathrm{Zn}$ & $\mathrm{Cu}$ & $\mathrm{Mn}$ & B & $\mathrm{C}$ & Lignin & $\mathrm{C}: \mathrm{N}$ & $C: P$ & Lignin: $N$ \\
\hline Yrs & & & & $\mathrm{g} \mathrm{kg}^{-1}$ & & - & & $-\mathrm{mg}$ & $\mathrm{g}^{-}$ & - & - & $\%$ & & & \\
\hline 2 & Footslope & $15.0 \mathrm{a}$ & $0.71 \mathrm{a}$ & $1.2 \mathrm{a}$ & $12.3 \mathrm{a}$ & $1.6 \mathrm{a}$ & $23.9 \mathrm{ab}$ & $12.4 \mathrm{a}$ & $1024 \mathrm{a}$ & $14.0 \mathrm{ab}$ & $52.28 \mathrm{a}$ & $35 \mathrm{a}$ & $33.9 \mathrm{a}$ & $645 a$ & $22.7 \mathrm{a}$ \\
\hline 4 & Footslope & $11.4 \mathrm{~b}$ & $0.62 b c$ & $0.9 \mathrm{ab}$ & $6.6 b$ & $1.3 \mathrm{~b}$ & $41.1 \mathrm{a}$ & $9.8 \mathrm{a}$ & $572 \mathrm{bc}$ & $7.9 b$ & $47.23 \mathrm{a}$ & $28 \mathrm{a}$ & $42.2 \mathrm{a}$ & $762 a$ & $25.0 \mathrm{a}$ \\
\hline 6 & Footslope & $11.5 \mathrm{~b}$ & $0.53 \mathrm{c}$ & $1.0 \mathrm{ab}$ & $8.9 b$ & $1.6 \mathrm{a}$ & $25.5 \mathrm{ab}$ & $9.1 \mathrm{a}$ & $348 \mathrm{c}$ & $5.8 \mathrm{~b}$ & $42.18 \mathrm{a}$ & $35 \mathrm{a}$ & $37.9 \mathrm{a}$ & $796 a$ & $31.5 \mathrm{a}$ \\
\hline 2 & Hillslope & $14.4 \mathrm{a}$ & $0.71 \mathrm{ab}$ & $1.0 \mathrm{ab}$ & $13.8 \mathrm{a}$ & $1.5 \mathrm{ab}$ & $24.1 \mathrm{ab}$ & $13.5 \mathrm{a}$ & $890 \mathrm{ab}$ & $17.7 \mathrm{a}$ & $48.89 \mathrm{a}$ & $32 a$ & $34.0 \mathrm{a}$ & $689 a$ & $22.3 \mathrm{a}$ \\
\hline 4 & Hillslope & $10.6 \mathrm{~b}$ & $0.53 \mathrm{c}$ & $0.7 \mathrm{bc}$ & $12.9 \mathrm{a}$ & $1.6 \mathrm{a}$ & $14.4 \mathrm{~b}$ & $9.3 \mathrm{a}$ & $605 \mathrm{ab}$ & $9.3 \mathrm{ab}$ & $47.60 \mathrm{a}$ & $36 a$ & $45.1 \mathrm{a}$ & $898 \mathrm{a}$ & $34.1 \mathrm{a}$ \\
\hline 6 & Hillslope & $11.0 \mathrm{~b}$ & $0.52 \mathrm{c}$ & $0.5 \mathrm{c}$ & $7.7 \mathrm{~b}$ & $0.8 \mathrm{c}$ & $15.7 \mathrm{~b}$ & $10.7 \mathrm{a}$ & $286 \mathrm{c}$ & $11.8 \mathrm{ab}$ & $54.34 \mathrm{a}$ & $31 \mathrm{a}$ & $48.5 \mathrm{a}$ & $1045 \mathrm{a}$ & $27.7 \mathrm{a}$ \\
\hline $\begin{array}{l}\text { Native } \\
\text { forest }\end{array}$ & Footslope & 18.6 & 0.90 & 1.6 & 23.8 & 2.5 & 37.8 & 16.5 & 603 & 33.7 & 50.00 & 37 & 26.8 & 556 & 19.9 \\
\hline
\end{tabular}

Means $(\mathrm{n}=3)$ at the same column followed by the same letter are not significantly by REGWQ test $(\mathrm{P}<0.05)$.

Table 2 - Total evolved $\mathrm{C}-\mathrm{CO}_{2}$ from soils under eucalypt, as affected by stand age, topographic position, temperature and moisture, after 106 days of incubation.

Tabela 2 - Total de C-CO emitido em solos sob eucalipto, conforme afetado pela idade do povoamento, posição topográfica, temperatura e umidade, durante 106 dias de incubação.

\begin{tabular}{|c|c|c|c|c|c|c|}
\hline Subplot & 2 & 4 & 6 & 2 & 4 & 6 \\
\hline \multirow[t]{2}{*}{ Soil } & \multicolumn{3}{|c|}{ Footslope } & \multicolumn{3}{|c|}{ Hillslope } \\
\hline & \multicolumn{6}{|c|}{$\mathrm{C}_{-} \mathrm{CO}_{2}\left(\mathrm{mg} \mathrm{g}^{-1}\right.$ soil $)$} \\
\hline $23^{\circ} \mathrm{C}$ & $0.658 * * * \mathrm{a}$ & $0.508^{\mathrm{ns}} \mathrm{a}$ & $0.537 * \mathrm{a}$ & $0.639^{\text {ns }} \mathrm{a}$ & $0.513^{\mathrm{ns}} \mathrm{a}$ & $0.473 * * \mathrm{a}$ \\
\hline $32^{\circ} \mathrm{C}$ & $1.346 \mathrm{a}$ & $0.632 b c$ & $0.937 \mathrm{~b}$ & $0.751 \mathrm{bc}$ & $0.553 \mathrm{c}$ & $0.918 b$ \\
\hline $40 \% \mathrm{FC}^{1}$ & $1.134^{\mathrm{ns}} \mathrm{a}$ & $0.587^{\mathrm{ns}} \mathrm{b}$ & $0.593^{\mathrm{ns}} \mathrm{b}$ & $0.638^{\text {ns }} b$ & $0.495^{\mathrm{ns}} \mathrm{b}$ & $0.704^{\mathrm{ns}} \mathrm{b}$ \\
\hline $80 \% \mathrm{FC}$ & $0.870 \mathrm{a}$ & $0.552 \mathrm{a}$ & $0.881 \mathrm{a}$ & $0.752 \mathrm{a}$ & $0.571 \mathrm{a}$ & $0.687 \mathrm{a}$ \\
\hline Non-fertilized & $1.044^{\mathrm{ns}} \mathrm{a}$ & $0.517^{\text {ns }} \mathrm{b}$ & $0.799^{\text {ns }} \mathrm{ab}$ & $0.641^{\mathrm{ns}} \mathrm{b}$ & $0.466^{\mathrm{ns}} \mathrm{b}$ & $0.573^{\text {ns }} \mathrm{b}$ \\
\hline Fertilized & $0.960 \mathrm{a}$ & $0.622 b$ & $0.675 \mathrm{ab}$ & $0.749 \mathrm{ab}$ & $0.600 \mathrm{~b}$ & $0.818 \mathrm{ab}$ \\
\hline Means & $1.002 \mathrm{a}$ & $0.570 \mathrm{~b}$ & $0.737 \mathrm{~b}$ & $0.695 b$ & $0.533 b$ & $0.695 b$ \\
\hline \multirow[t]{2}{*}{ Soil + Litter } & & Footslope & & & Hillslope & \\
\hline & \multicolumn{6}{|c|}{$\mathrm{C}_{-} \mathrm{CO}_{2}\left(\mathrm{mg} \mathrm{g}^{-1}\right.$ soil $)$} \\
\hline $23^{\circ} \mathrm{C}$ & $4.416^{*} \mathrm{a}$ & $4.514^{* *} \mathrm{a}$ & $4.667^{\mathrm{ns}} \mathrm{a}$ & $4.967^{\mathrm{ns}} \mathrm{a}$ & $4.117^{\mathrm{ns}} \mathrm{a}$ & $4.807^{\mathrm{ns}} \mathrm{a}$ \\
\hline $32^{\circ} \mathrm{C}$ & $5.567 \mathrm{a}$ & $6.256 \mathrm{a}$ & $5.682 \mathrm{a}$ & $4.775 \mathrm{a}$ & $4.572 \mathrm{a}$ & $4.587 \mathrm{a}$ \\
\hline $40 \% \mathrm{FC}$ & $5.079^{\mathrm{ns}} \mathrm{ab}$ & $5.702^{\text {ns }} \mathrm{a}$ & $4.955^{\mathrm{ns}} \mathrm{ab}$ & $5.293^{\mathrm{ns}} \mathrm{ab}$ & $4.479^{\mathrm{ns}} \mathrm{b}$ & $4.493^{\text {ns }} \mathrm{b}$ \\
\hline $80 \% \mathrm{FC}$ & $4.904 \mathrm{a}$ & $5.068 \mathrm{a}$ & $5.394 \mathrm{a}$ & $4.449 \mathrm{a}$ & $4.211 \mathrm{a}$ & $4.901 \mathrm{a}$ \\
\hline Non-fertilized & $4.886^{\mathrm{ns}} \mathrm{a}$ & $5.549^{\text {ns }} \mathrm{ab}$ & $5.109^{\mathrm{ns}} \mathrm{ab}$ & $4.639^{\mathrm{ns}} \mathrm{ab}$ & $4.400^{\mathrm{ns}} \mathrm{b}$ & $4.675^{\text {ns }} \mathrm{ab}$ \\
\hline Fertilized & $5.097 \mathrm{a}$ & $5.221 \mathrm{a}$ & $5.240 \mathrm{a}$ & $5.103 \mathrm{a}$ & $4.289 \mathrm{a}$ & $4.719 \mathrm{a}$ \\
\hline Means & $4.991 \mathrm{ab}$ & $5.385 \mathrm{a}$ & $5.174 \mathrm{a}$ & $4.871 \mathrm{ab}$ & $4.345 \mathrm{~b}$ & $4.697 \mathrm{ab}$ \\
\hline
\end{tabular}

Means $(\mathrm{n}=3$ ) followed by the same lowercase letter (at rows) are not significantly different by the LS means test (P<0.05). Significant differences between the two levels of each factor are indicated by $*(\mathrm{P}<0.05), * *(\mathrm{P}<0.01), * * *(\mathrm{P}<0.001)$, ns $($ non-significant $)$.

\section{DISCUSSION}

\subsection{C-CO $\mathrm{C}_{2}$ evolved from soil and leaf litter}

The non-significant effect of substrate moisture and fertilization indicates that $40 \%$ water holding capacity and current soil fertility were sufficient for an optimal soil respiration in this study. Correlations between $\mathrm{CO}_{2}$ emission rates and water content vary according to soil moisture conditions. Kiese and Butterbach-Bahl (2002) reported that $\mathrm{CO}_{2}$ emission rates were positively correlated with moisture in dry soils, but negatively correlated when water-filled pores were $>50-60 \%$, because of limited $\mathrm{O}_{2}$ diffusion in the soil matrix. Other authors proposed that $\mathrm{C}$-mineralization and $\mathrm{CO}_{2}$ emission rates are incremented by drying and wetting cycles (VANGESTEL et al., 1993; FIERER; SCHIMEL, 2002). 
In the present study, C-CO $\mathrm{C}_{2}$ evolved from soils under ages 2 and 6 yrs were respectively 60 and $100 \%$ higher at $32^{\circ} \mathrm{C}$ compared to $23{ }^{\circ} \mathrm{C}$. Vasconcellos (1994) and Grisi et al. (1998) incubated different Brazilian soils at $15^{\circ} \mathrm{C}$ and $35^{\circ} \mathrm{C}$ and found differences between treatments only at $35^{\circ} \mathrm{C}$. This suggests that microbial

Hillslope, $23^{\circ} \mathrm{C}$

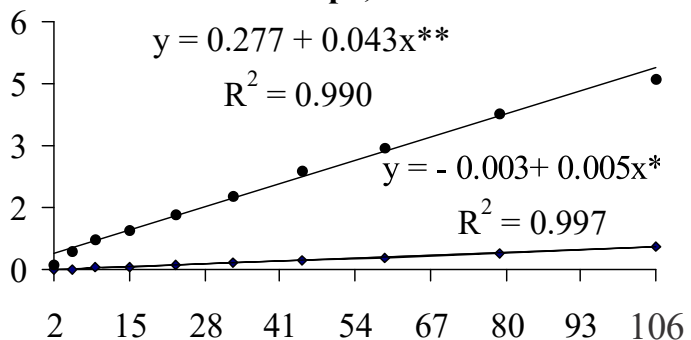

Footslope, $23{ }^{\circ} \mathrm{C}$

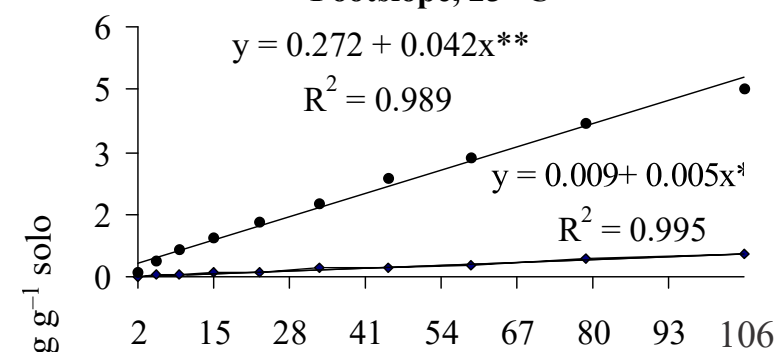

Native forest

Footslope, $2^{\circ} \mathrm{C}$

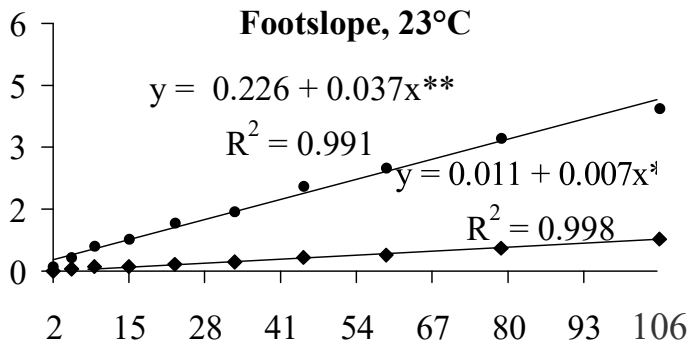

activity for these tropical soils is triggered above 15 ${ }^{\circ} \mathrm{C}$, most likely between 15 and $23{ }^{\circ} \mathrm{C}$.

Despite the initially higher N, P and Ca concentrations in leaf litter under 2-yr-old stands (Table 1), there were no differences due to age in total $\mathrm{C}-\mathrm{CO}_{2}$ evolved when leaf fragments were added on soils (Tables 2 ). This

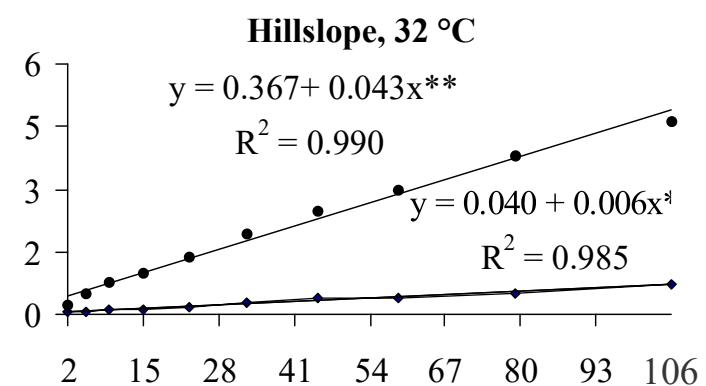

Footslope, $32^{\circ} \mathrm{C}$

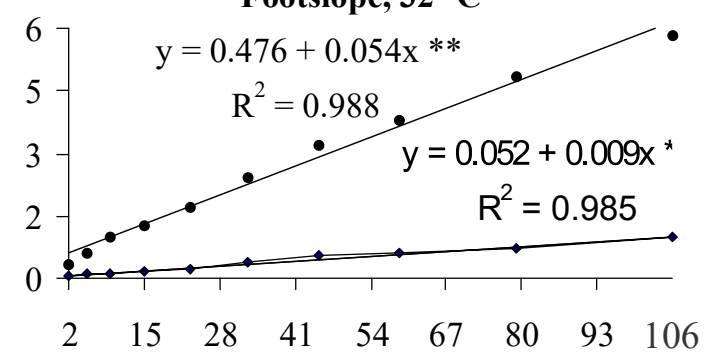

Native forest

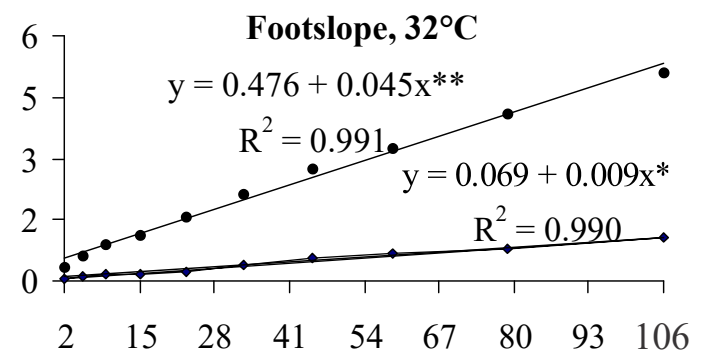

Time (days)

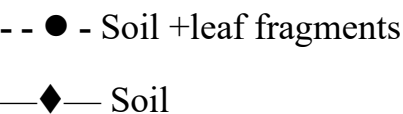

Figure 1 - Evolved C- $\mathrm{CO}_{2}\left(\mathrm{mg} \mathrm{g}^{-1}\right.$ soil) from soils and soil+leaf fragments under eucalypt forest (means of 3 stand ages) and native forest, affected by topographic position and temperature, during 106 days of incubation.

Figura 1 - Emissão de $\mathrm{C}-\mathrm{CO}_{2}\left(\mathrm{mg} \mathrm{g}^{-1}\right.$ soil), em solos e fragmentos foliares sobre o solo, em florestas de eucalipto (média de três idades) e floresta nativa, conforme afetada pela posição topográfica e temperatura, durante 106 dias de incubação. 


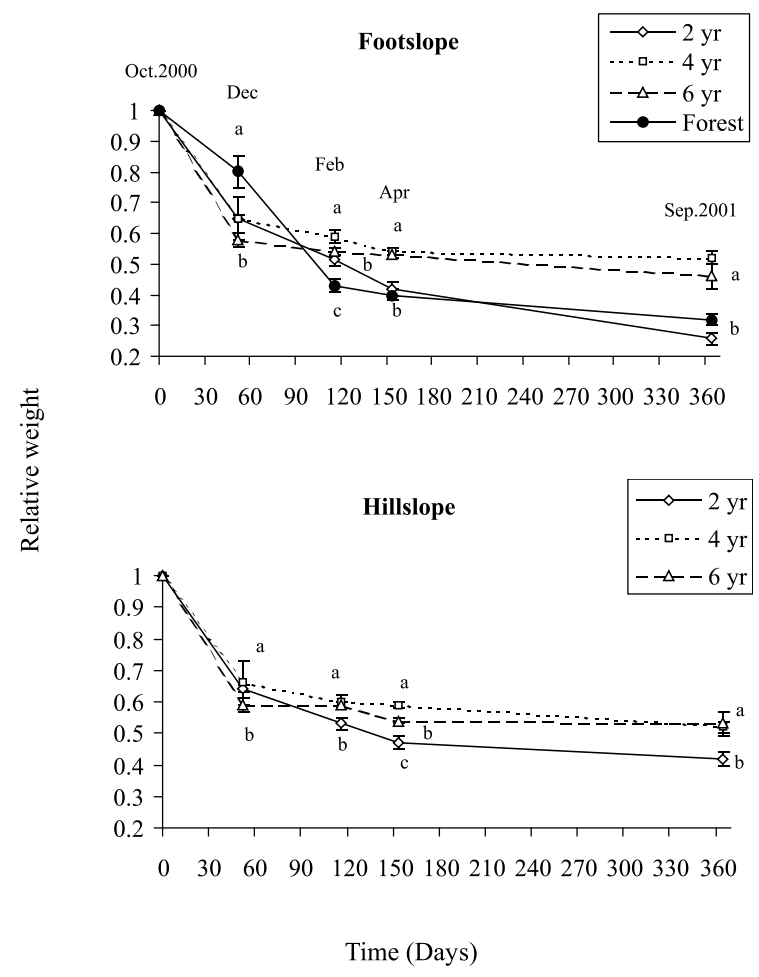

Figure 2 - Litterbag weight loss of 2, 4, 6 yr-eucalypt stands on footslope and hillslope and a native forest on footslope, from Oct. $24^{\text {th }} 2000$ to Oct $24^{\text {th }} 2001$.

Figura 2-Decomposição foliar (litterbags) em povoamentos de eucalipto nas idades de 2, 4 e 6 anos sob baixada e encosta e uma floresta nativa sob baixada, de 24 de outubro de 2000 a 24 de outubro de 2001.

indicates that substrate quality was not a limiting factor to microbial activity, which is corroborated by the nonsignificant effect of fertilization. Fertilization of eucalypt stands has been shown to increase mineralization of added nutrients, but not litter decomposition rates (RIBEIRO etal., 2002; O'CONNELL; MENDHAM, 2004). Soil respiration on footslopes was higher than on hillslopes, despite the similar substrate chemistry (Table 1). This difference may be caused by a diverse microbial composition, since more mycelia were visible on footslope samples. The constant rates of $\mathrm{C}-\mathrm{CO}_{2}$ release from soils and soil + leaf litter (Figure 1) indicated a homogeneous lability of the organic substrates respired during the 106 days incubation.

The similar soil respiration rates between eucalypt and native forest on footslopes contrasts with the reportedly higher values for soils under native forest, usually higher in soil organic carbon, fertility and $\mathrm{pH}$ (DELLA BRUNA et al., 1991; FIALHO et al., 1991; CARVALHO et al., 1997; SODRÉ, 1999; ASSIS JÚNIOR et al., 2003). This trend indicates that labile $\mathrm{C}$ pools are equivalent, and the higher soil organic matter under native forest is mostly in stable forms that did not undergo decomposition during the incubation period. In Oxisols, the recalcitrant pool of soil organic matter associated to Fe/Al hydroxides and clays controls mineralization of N (SIERRA; MARBÁN, 2000) and probably also $\mathrm{C}$. The similarity between the two vegetation types also occurred when leaf litter was added on soil, which suggests similar leaf litter quality, despite the lower nutrient contents and higher C:N, C:P and lignin: $\mathrm{N}$ ratio in eucalypt litter (Table 1). Accordingly, earlystage $\mathrm{CO}_{2}$ release from eucalypt and other tree species litter was not affected by initial $\mathrm{N}$ and lignin contents (BERNHARD-REVERSAT, 1998). Fisher and Binkley (2000) pointed out that litter quality indicators such as $\mathrm{C}: \mathrm{N}$ and lignin: $\mathrm{N}$ do not always relate well to field and laboratory decomposition, which restricts their wide use. Luo and Zhou (2006) agree that multiple interacting factors render soil respiration understanding very difficult.

Literature data from in vitro studies showed that mean daily soil respiration for eucalypt stands and native/secondary forests in Brazil is 0.015 and $0.03 \mathrm{mg}$ $\mathrm{C}-\mathrm{CO}_{2} \mathrm{~g}^{-1}$ soil $\mathrm{d}^{-1}$, respectively (Table 3 ). These values are proportional to the mean soil organic carbon concentrations of 20.5 and $26.5 \mathrm{~g} \mathrm{~kg}^{-1}$, for eucalypts and native vegetation, respectively. In this study, mean soil respiration from eucalypt and native forest were

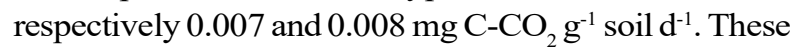
values are low compared with the means and similar only to those of low-carbon soils in Table 3, and may be caused by lower soil organic carbon contents.

\subsection{Litterbags}

The significant effect of topography on C-CO evolved in vitro by both soil and soil+leaf fragments was reflected into higher decomposition in situ only for 2 -yr old stands, which lost $74 \%$ of litterbag weight on footslopes, compared to $58 \%$ on hillslopes.

Leaf litter decomposition was faster in the youngest eucalypt stands, as reported for branch litter in India (BARGALI, 1996). The effect of stand age on litter decomposition in situ, but not on $\mathrm{C}-\mathrm{CO}_{2}$ emission in vitro, suggests differential responses by decomposer 
Table 3 - Overall means for soil organic carbon, $\mathrm{C}-\mathrm{CO}_{2}$ evolved from soil and leaf litter on soil, under eucalypt plantation, and native/secondary vegetation in Brazil.

Tabela 3 - Médias gerais de carbono orgânico do solo, $\mathrm{C}-\mathrm{CO}_{2}$ emitido do solo e de folhas fragmentadas sobre o solo, sob plantação de eucalipto e vegetação nativa ou secundária, no Brasil.

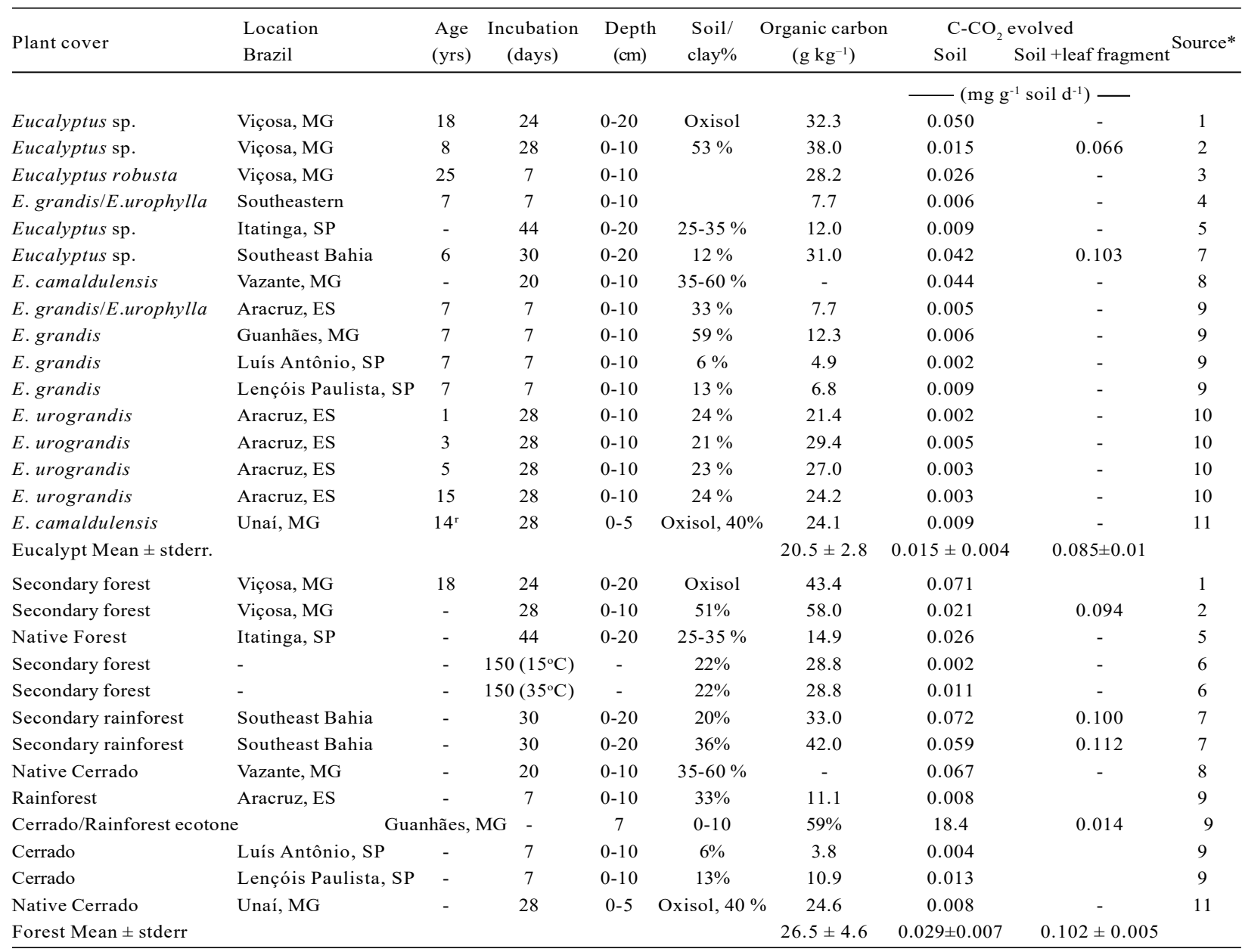

*1. Fialho et al. (1991); 2. Della Bruna et al. (1991); 3. Gama-Rodrigues et al. (1997); 4. Gama-Rodrigues (1997); 5. Carvalho et al. (1997); 6. Grisi et al. (1998); 7. Sodre (1999); 8. Assis Junior et al. (2003); 9. Gama-Rodrigues et al. (2008); 10. Barreto et al. (2010); 11. Zinn et al. (2011).

communities. The remaining litter mass after 365 days was higher for eucalypt ( $41 \%$, mean of three ages) on footslopes than for the native forest (32\%). These values represent a much faster decomposition than reported by Costa et al., (2005) for eucalypt plantations in Rio de Janeiro. Differences in nutritional quality between vegetation types, and also among eucalypt ages, may have influenced the activity of larger decomposers (meso and macrofauna) rather than soil microbiota. Litter decomposition is influenced by substrate quality and climate (AERTS, 1997), but also by the physical- chemical environment and decomposer organisms (GONZALES; SEASTEDT, 2001). Lack of decomposer fauna was suggested by Mesquita, Workman and Neely (1998) as responsible for slow decomposition in a Cecropia-dominated secondary rainforest in Amazon. The main decomposing fauna may vary according to the landscape, vegetation and period. On footslopes in this study, ants were common in both native forest and eucalypts, whereas earthworms were noted only under eucalypt stands. In an Amazon upland rainforest, Cornu et al. (1997) observed the dominance of

Revista Árvore, Viçosa-MG, v.39, n.6, p.1055-1064, 2015 
earthworms and termites, the latter responsible for $40 \%$ of the litter disappearance in the wetter period (LUIZÃO; SCHUBART, 1987). Decomposition of eucalypt leaf litter by termites was reported by BernhardReversat and Schwartz (1997) in Congo.

Paul and Polglase (2004) suggested that rainfall and temperature explain better decomposition in situ than litter chemistry alone. Investigating the initial three months of Eucalypt litter decomposition in Congo, Ngao et al. (2009) reported that C mineralization were first driven by soluble organic compounds and then by soluble phenolic compounds, but relations between litter quality and decomposition varied strongly in the dry and rainy seasons. Sierra and Marbán (2000) reported higher $\mathrm{N}$ mineralization in clayey Oxisols with increasing water content, especially for acid soils and temperatures $>30^{\circ} \mathrm{C}$. Sierra (2002) reported that $\mathrm{N}$ mineralization was higher under fluctuating than under constant temperature, and higher temperatures had a stronger effect on recalcitrant than on labile N. Eucalypt leaf decomposition in this study was faster than reported for native species in Caribbean islands (LORANGER; PONGE, 2002) and Amazon rainforest (MESQUITA; WORKMAN; NEELY, 1998; SMITH et al., 1998), comparable to legume tree plantations in Amazon (SMITH et al., 1998), and lower than in Mexican rainforest (ALVAREZ-SÁNCHES; ENRÍQUEZ, 1996).

\section{CONCLUSIONS}

Data presented here suggest that no inherent limitations to decomposition of eucalypt litter in the studied sites occur. Thus, the large litter layer stocks reported are most likely due to intense litter production in the area. The differences in decomposition patterns of eucalypt and native forest litter are most likely related to the respective soil decomposer communities and their response to rainfall.

\section{ACKNOWLEDMENTS}

We gratefully acknowledge the sponsorship by CNPq to the first author and the substantial support by Cenibra S.A., Ipatinga, MG, especially to Dr. Fernando P. Leite for providing all facilities during the sampling and part of laboratory work. The Incubation was conducted in the Departamento de Microbiologia at Universidade Federal de Viçosa (UFV), MG, Brazil. Our thanks to Drs. Maria C. M. Kasuya and Marcos R. Tótola for the laboratory support and to Dr. Haroldo N. de Paiva (Dept. Engenharia Florestal, UFV) for the suggestions.

\section{REFERENCES}

ALVAREZ-SÁNCHES, A.; ENRÍQUEZ, R.B. Leaf decomposition en a tropical rain forest. Biotropica, v.28, n.4b, p.657-667, 1996.

ANDERSON, J.P.E. Soil respiration. In: PAGE, A.L.; MILLER, R.H.; KEENEY, D.R. (Ed.) Methods of soil analysis; chemical and microbiology properties. Madison: American of Society of Agronomy and Soil Science Society of America, 1982. Pt. 2. p.831-871.

AERTS, R. Climate, leaf litter chemistry and leaf litter decomposition in terrestrial ecosystems: a triangular relationship. Oikos, v.70, n.3, p.439449, 1997.

ASSIS JÚNIOR, S.L.; ZANUNCIO, J.C.; KASUYA, M.C.M.; COUTO, L.; MELIDO, R.C.N. Atividade microbiana do solo em sistemas agroflorestais, monoculturas, mata natural e área desmatada. Revista Árvore, v.27, n.1, p.35-41, 2003.

BARGALI, S.S. Weight loss and $\mathrm{N}$ release in decomposing wood litter in a eucalypt plantation age series. Soil Biology and

Biochemistry, v.28, n.4/5, p.699-702, 1996.

BARRETO, P.A.B.; GAMA-RODRIGUES, E.F.; GAMA-RODRIGUES, A.C.; BARROS, N.F.; ALVES, B.J.R.; FONSECA, S. Mineralização de nitrogênio e carbono em solos sob plantações de eucalipto, em uma sequência de idades. Revista

Brasileira de Ciência do Solo, v.34, n.3, p.735-745, 2010.

BERNHARD-REVERSAT, F.; SCHWARTZ, D.

Change in lignin content during litter decomposition in tropical forest soils (Congo): comparison of exotic plantations and native stands. Comptes Rendus de la Académie de Sciences de Paris: Sciences de la Terre et Planetes, v.325, n.6, p.427-432, 1997.

BERNHARD-REVERSAT, F. Changes in relationships between initial litter quality and $\mathrm{CO}_{2}$ release during early laboratory decomposition of 
tropical leaf litters. European Journal of Soil Biology, v.43, n.3, p.117-122, 1998.

BREMNER, J.M.; MULVANEY, C.S. Nitrogen-total. In: PAGE, A.L. (Ed.). Method of Soil Analysis; Chemical and Microbiological Properties. Madison: American Society of Agronomy and Soil Science Society of America, 1982. Pt 2. p. 595-624.

CARVALHO, M.C.S.; SILVA, M.A.G.; TORMENA, C.A.; GONÇALVES, J.L.M. Atividade microbiana de um Latossolo Vermelho Escuro álico sob eucalipto e mata nativa. In: CONGRESSO BRASILEIRO DE CIÊNCIA DO SOLO, 26., 1997, Rio de Janeiro. Anais... Rio de Janeiro: Sociedade Brasileira de Ciência do Solo, 1997. (CD ROM).

CORNU, S.; LUIZÃO, F.; ROUILLER, J.; LUCAS, Y. Comparative study of litter decomposition and mineral element release in two Amazonian forest ecosystems: litter bag experiments.

Pedobiologia, v.41, p.456-469, 1997.

COSTA, G.S.; GAMA-RODRIGUES, A.C.; CUNHA, G.M. Decomposição e liberação de nutrientes da serapilheira foliar em povoamentos de Eucalyptus grandis no norte Fluminense. Revista Árvore, v.29, n.4, p.563-570, 2005.

DELLA BRUNA, E.; BORGES, A.C.; FERNANDES, B.; BARROS, N.F.; MUCHOVEJ, R.M.C. Atividade da microbiota de solos adicionados de serapilheira e de nutrientes. Revista Brasileira de Ciência do Solo, v.15, n.1, p.15-20, 1991.

FIALHO, J.F; BORGES, A.C.; BARROS, N.F Cobertura vegetal e as características químicas e físicas e atividade da microbiota de um Latossolo Vermelho-Amarelo distrófico. Revista

Brasileira de Ciência do Solo, v.15, n.1, p.21-28, 1991.

FIERER, N.; SCHIMEL, J.P. Effects of dryingrewetting frequency on soil carbon and nitrogen transformations Soil Biology and Biochemistry, v.34, n.6, p.777-787, 2002.

FISHER, R.F.; BINKLEY, D. Forest Biogeochemistry. In: FISHER, R.F.; BINKLEY, D.
(Ed.) Ecology and management of forest soils. New York: John Wiley \& Sons, 2000. p.184240.

GAMA-RODRIGUES, E.F. Carbono e nitrogênio da biomassa microbiana do solo e da serapilheira de povoamentos de eucalipto. 1997. 108f. Tese (Doutorado em Ciência do Solo) - Universidade Federal Rural do Rio de Janeiro, Seropédica, 1997.

GAMA-RODRIGUES, E.F.; GAMA-RODRIGUES, A.C.; BARROS, N.F. Biomassa microbiana de carbono e de nitrogênio de solos sob diferentes coberturas florestais. Revista Brasileira de Ciência do Solo, v.21, n. 3, p.361-365, 1997.

GAMA-RODRIGUES, E.F.; BARROS, N.F.; VIANA, A.P.; SANTOS, G.A. Alterações na biomassa e na atividade microbiana da serapilheira e do solo, em decorrência da substituição de cobertura florestal nativa por plantações de eucalipto, em diferentes sítios da Região Sudeste do Brasil. Revista Brasileira de Ciência do Solo, v.32, n.4, p.1489-1499, 2008.

GONZÁLEZ, G.; SEASTEDT, T.R. Soil fauna and plant litter decomposition in tropical and subalpine forests. Ecology, v. 82, n.4, p.955-964, 2001.

GRISI, B; GRACE, C; BROOKES, P.C; BENEDETTI, A; DELL'ABATE, M.T. Temperature effects on organic matter and microbial biomass dynamics in temperature and tropical soils. Soil Biology and Biochemistry, 30, n.10/11, p.1309-1315, 1998.

KIESE, R; BUTTERBACH-BAHL, K. $\mathrm{N}_{2} \mathrm{O}$ and $\mathrm{CO}_{2}$ emissions from three different tropical forest sites in the wet tropics of Queensland, Australia. Soil Biology and Biochemistry, v.34, n.7, p.975$987,2002$.

JONES, J.B.; CASE, V.W. Sampling, Handling, and Analysis Plant Tissue Samples. In: WESTERMAN, R.L. (Ed.). Soil Testing and Plant Analysis. Madison: American Society of Agronomy and Soil Science Society of America, 1990. p.389-427.

LORANGER, G.; PONGE, J.F. Leaf decomposition in two semi-evergreen forests: influence of litter

Revista Árvore, Viçosa-MG, v.39, n.6, p.1055-1064, 2015 
quality. Biology and Fertility of Soils, v.35, n. 3, p.247-252, 2002.

\section{LUO, Y.; ZHOU, X. Soil respiration and} the environment. San Diego: Elsevier, 2006. $316 \mathrm{p}$.

LUIZÃO, F.J.; SCHUBART, H.O.R. Litter production and decomposition in a "terra firme" forest of Central Amazonia. Experientia v.43, n.3, p.259-265, 1987.

MESQUITA, R.C.G.; WORKMAN, S.W.; NEELY, C.L. Slow litter decomposition in a Cecropiadominated secondary forest of Central Amazonia. Soil Biology and Biochemistry, v.30, n.2, p.167-175, 1998.

NGAO, J.; BERNHARD-REVERSAT, F.;

LOUMETO, J.J. Changes in eucalypt litter quality during the first three months of field decomposition in a Congolese plantation. Applied Soil Ecology, v.42, n.3, p.191-199, 2009.

O'CONNELL, AM.; MENDHAM, D.S. Impact of N and $\mathrm{P}$ fertilizer application on nutrient cycling in Jarrah (Eucalyptus marginata) forests of South Western Australia. Biology and Fertility of Soils, v.40, n.2, p.136-143, 2004.

OLSEN, S.R.; SOMMERS, L.E. Phosphorus. Method of soil analysis; chemical and microbiological properties. In: PAGE, A.L. (Ed.). Madison: American Society of Agronomy and Soil Science Society of America, 1982. Pt 2. p.403-430.

PAUL K.I.; POLGLASE, P.J. Prediction of decomposition of litter under eucalypts and pines using the FullCAM model. Forest Ecology and Management, v.191, n.1, p.73-92, 2004.

PRESCOTT, C.E. Do rates of litter decomposition tell us anything we really need to know? Forest Ecology and Management, v.220, n.1-3, p.66-74, 2005.

RIBEIRO, C.; MADEIRA, M.; ARAUJO, M.C. Decomposition and nutrient release from leaf litter of Eucalyptus globulus grown under different water and nutrient regimes. Forest Ecology and Management, v.171, n.1, p.31-41, 2002.

SAS Institute - SAS/STAT User's Guide. 1990. version 6. Cary: 1990.

SIERRA, J.; MARBÁN, L. Nitrogen mineralization pattern of an Oxisol of Guadeloupe, French West Indies. Soil Science Society of America Journal, v.64, n.6, p.2002-2010, 2000.

SIERRA, J. Nitrogen mineralization and nitrification in a tropical soil: effects of fluctuating temperature conditions. Soil Biology and Biochemistry, v.34, n.8, p.1219-1226, 2002.

SMITH, C.K.; GHOLZ, H.L.; ASSIS OLIVEIRA, F. Fine litter chemistry, early-stage decay, and nitrogen dynamics under plantations and primary forest in lowland Amazonia. Soil Biology and Biochemistry, v.30, n.14, p.2159-2169, 1998.

SODRÉ, G.A. Qualidade da serapilheira de mata natural, capoeira, pastagem e plantios de eucalipto no sudeste da Bahia. 1999. 80f. Dissertação (Mestrado em Ciência do Solo) - Universidade Federal de Viçosa, Viçosa, MG. 1999.

van SOEST, P.; WINE, R.H. Development of a comprehensive system of feed analysis and its application to forages. Journal of the Association of the Official Agricultural Chemists, v.51, n.4, p.780785,1968 .

VANGESTEL, M.; MERCKX, R.; VLASSAK, K. Microbial biomass and activity in soils with fluctuating water contents. Geodinamica Acta, v.56, p.617-626, 1993.

VASCONCELLOS, C.A. Temperature and glucose effects on soil organic carbon: $\mathrm{CO}_{2}$ evolved and decomposition rate. Pesquisa Agropecuária Brasileira, v.9, n.7, p.1129-1136, 1994.

ZINN, Y.L.; LAL, R.; RESCK, D.V.S. Eucalypt plantation effects on organic carbon and aggregation of three different-textured soils in Brazil. Soil Research, v.49, n.7, p.614-624, 2011. 